\title{
Understanding the health and housing experiences of refugees and other migrant populations experiencing homelessness or vulnerable housing: a systematic review using GRADE-CERQual
}

\author{
Harneel Kaur MD, Ammar Saad MSc, Olivia Magwood MPH, Qasem Alkhateeb MD, \\ Christine Mathew MSc, Gina Khalaf MD, Kevin Pottie MD MClSc
}

\section{Abstract}

Background: A growing number of migrants experience precarious housing situations worldwide, but little is known about their health and housing experiences. The objective of this study was to understand the enablers and barriers of accessing fundamental health and social services for migrants in precarious housing situations.

Methods: We conducted a systematic review of qualitative studies. We searched the databases of MEDLINE, PsycINFO, CINAHL, Scopus, Web of Science, Social Sciences, Canadian Business \& Current Affairs and Sociological Abstracts for articles published between Jan. 1, 2007, and Feb. 9, 2020. We selected studies and extracted data in duplicate, and used a framework synthesis approach, the Bierman model for migration, to guide our analysis of the experiences of migrant populations experiencing homelessness or vulnerable housing in high-income countries. We critically appraised the quality of included studies using the Critical Appraisal Skills Programme checklist and assessed confidence in key findings using the Grading of Recommendations Assessment, Development and Evaluation Confidence in the Evidence from Reviews of Qualitative Research (GRADE-CERQual) approach.

Results: We identified 1039 articles, and 18 met our inclusion criteria. The studies focused on migrants from Asia and Africa who resettled in Canada, Australia, the United States, the United Kingdom and other European countries. Poor access to housing services was related to unsafe housing, facing a family separation, insufficient income assistance, immigration status, limited employment opportunities and lack of language skills. Enablers to accessing appropriate housing services included finding an advocate and adopting survival and coping strategies.

Interpretation: Migrants experiencing homelessness and vulnerable housing often struggle to access health and social services; migrants may have limited proficiency with the local language, limited access to safe housing and income support, and ongoing family insecurities. Public health leaders could develop outreach programs that address access and discrimination barriers. PROSPERO Registration: CRD42018071568

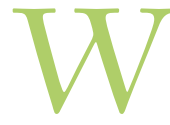
orldwide, more than 272 million people are classified as "international migrants". ${ }^{1}$ Migrant populations include refugees, asylum seekers, displaced persons and immigrants who move from their country of residence to another. ${ }^{2,3}$ Literature suggests that homelessness may be prevalent among migrants to different countries. ${ }^{4-6}$ Within North America, evidence highlights a substantial movement of undocumented migrants from the United States into Canada. ${ }^{7}$

Refugees and other migrants who are precariously housed may couch surf, or live in motels and other short-term rentals. When these options fail, they turn to temporary homeless shelters. ${ }^{8,9}$ In contrast to government-assisted refugee shelters, homeless shelters lack language and cultural food resources, and other health, education and employment resettlement infrastructure. ${ }^{8}$ Forced displacement and marginalization can create additional challenges in securing safe and stable housing for migrants, ${ }^{10}$ with many experiencing homelessness at some point in their resettlement process. The magnitude of visible or hidden migrant homelessness is largely unknown

\section{Competing interests: None declared.}

This article has been peer reviewed.

Correspondence to: Kevin Pottie, kpottie@uottawa.ca

CMAJ Open 2021. DOI:10.9778/cmajo.20200109 
and what little evidence exists is of low quality, which limits the development of policies, programs and services that address homelessness among migrants.

Field research suggests that the risk of migrant homelessness increases with cuts to social programs, persistent health issues, poverty, lack of affordable housing, unrecognized education credentials, unemployment, delays in obtaining work permits, deinstitutionalization and lack of discharge planning. ${ }^{11}$ Mobile migrants are also at risk for frostbite, infectious diseases, soft-tissue infections, traumatic injuries and chronic illnesses (e.g., diabetes, cardiovascular disease). ${ }^{12,13}$ Furthermore, migrants may suffer from common mental illnesses, including posttraumatic stress disorder and depression. ${ }^{14}$ Migrant populations may also struggle with food insecurity and impaired access to health and social services. ${ }^{15-17}$

The objective of this systematic review was to understand the enablers and barriers of accessing fundamental health and social services for migrants who found themselves in precarious housing situations.

\section{Methods}

\section{Study design}

We conducted a systematic review according to a registered protocol (PROSPERO CRD42018071568; Appendix 1, available at www.cmajopen.ca/content/9/2/E681/suppl/DC1). ${ }^{19}$ We reported our findings according to the Preferred Reporting Items for Systematic Reviews and Meta-Analyses (PRISMA) reporting guideline. ${ }^{20}$

\section{Search strategy}

With the assistance of an information scientist librarian, we developed a search strategy using a combination of subject headings and keywords, including "migrant," "refugee," "asylum seeker," "homeless," "unsheltered" and "street." The primary search strategy is presented in Appendix 2, available at www.cmajopen.ca/content/9/2/E681/suppl/DC1. We used this strategy, and its translated versions, to systematically search the databases of MEDLINE, PsycINFO, CINAHL, Scopus, Web of Science, Social Sciences, Canadian Business \& Current Affairs and Sociological Abstracts for relevant studies from 2007 to Feb. 9, 2020. We did not apply any filters or language restrictions. We did not systematically search for additional studies in reference lists or grey literature.

We originally searched bibliographical databases from the date of their inception; however, we soon recognized that evidence published since 2007 represents a reflection of a scholarly evolution in the field of migration and global health research, characterized by an exponential increase in the rate of research articles published in peer-reviewed journals. ${ }^{18}$ As a result, we decided to deviate from protocol and restrict the date of publication from 2007 onward at the full-text screening phase of the review.

\section{Eligibility criteria}

We included studies in our systematic review if they used a qualitative or mixed method design and were published between 2007 and 2020, in any language. We focused on studies whose participants were refugees, asylum seekers or undocumented migrants who were presently residing in highincome countries, as defined by the World Bank. ${ }^{21} \mathrm{We}$ restricted our studies to high-income settings, given the relative homogeneity in how migrants integrate into the labour market ${ }^{22}$ and the similar challenges they face when accessing health and social welfare services. ${ }^{23,24} \mathrm{We}$ included studies that reported on the barriers and facilitators that migrants face when accessing housing or shelter, and their health and wellbeing. Full inclusion and exclusion criteria, and a detailed description of study populations, interventions, controls and outcomes can be found in Appendix 3, available at www.cmaj open.ca/content/9/2/E681/suppl/DC1.

\section{Study selection and data collection}

Four team members (H.K., C.M., A.S., Q.A.) screened and selected titles, abstracts and full-text articles, independently and in duplicate. At the full-text screening stage, we limited articles to those published between Jan. 1, 2007, and Feb. 9, 2020, as noted earlier. All conflicts were resolved through discussion or by consulting a third reviewer (K.P.).

After study selection, we developed a standardized data extraction sheet that included study methodology, participant characteristics and contextual findings, including labour market conditions, immigration policies, social networks, neighbourhood characteristics, discrimination, income, education and language. We piloted the data extraction form to ensure relevancy (H.K., G.K.). Five reviewers (H.K., G.K., O.M., A.S., Q.A.) extracted data independently and in duplicate, and any conflicts were resolved with the help of a third reviewer (K.P.).

\section{Data analysis}

We assessed the methodological quality of included articles using the Critical Appraisal Skills Programme checklist for qualitative studies $^{25}$ (H.K., G.M., O.M., A.S.) (Appendix 4, available at www.cmajopen.ca/content/9/2/E681/suppl/DC1). We used the best-fit framework method as a systematic and flexible approach to analyzing the qualitative data. ${ }^{26-28}$ Framework analysis is a 5-stage process that includes familiarization with the data, identifying a thematic framework, indexing (applying the framework), charting and mapping, and interpretation. ${ }^{29} \mathrm{We}$ selected the Bierman model for migrant health as our framework. ${ }^{30}$ The Bierman model is a conceptual framework that considers the intersection of social determinants of health, gender equity, racial and ethnic disparities in health, and the migration experience. ${ }^{31}$

One reviewer (H.K.) coded the data into the domains of the Bierman model using a matrix spreadsheet to facilitate analysis; a second reviewer (K.P.) verified the coding. The review team (H.K., O.M., A.S., K.P.) identified and interpreted key findings through discussion with the review team. For the purposes of this review, we defined a review finding as an analytic output from our qualitative evidence synthesis that describes a phenomenon or an aspect of a phenomenon, based on data (participant quotations or author observation) from primary studies. $^{32}$ 
We used the Grading of Recommendations Assessment, Development and Evaluation Confidence in the Evidence from Reviews of Qualitative Research (GRADE-CERQual) approach. ${ }^{33,34}$ This approach evaluates findings on 4 criteria: methodological limitations of included studies supporting a review finding, the relevance of included studies to the review question, the coherence of the review finding and the adequacy of the data contributing to a review finding (Table 1).

\section{Ethics approval}

Ethics approval was not required for this study.

\section{Results}

Our search initially identified 1039 unique articles; however, after the initial removal of duplicates, we found 754 additional duplicate citations. We further screened articles to exclude low-income countries, and study populations and designs that did not meet inclusion criteria. We included 18 studies in our analysis (Figure 1).

\section{Study characteristics}

Eight studies focused specifically on refugees, ${ }^{6,35-41}$ and the remaining 10 studies considered the broader migrant populations, including immigrants, newcomers or refugees. ${ }^{42-51}$ Resettlement countries included Canada $(n=9)$, Australia $(n=4)$, Belgium $(n=1)$, Denmark $(n=1)$, Norway $(n=1)$, the United Kingdom $(n=1)$ and the US $(n=1)$. All included studies followed a naturalistic inquiry approach, except for 3 that had a comparison group. ${ }^{45,48,49}$ The characteristics of included studies and the methodological quality of studies are found in Table 2.

The Bierman model (Appendix 5, available at www.cmaj open.ca/content/9/2/E681/suppl/DC1) provided conceptual categories that we used to map and characterize our qualitative findings. In doing so, we identified 8 distinct findings from the included studies, summarized in Table 3 . The confidence in the findings ranged from very low to moderate, with 4 of the findings being of moderate confidence. Appendix 6, available at www.cmajopen.ca/content/9/2/E681/suppl/DC1, provides a detailed description of the findings. Of note, several factors from within the Bierman model had limited data available during the extraction process, including political environment, education and other factors.

\section{Barriers to accessing housing services}

\section{Interpersonal racism}

Two common barriers to accessing stable and secure housing for migrants were discrimination and stigmatization, often based on race, gender, socioeconomic status, language of origin, housing situation, trauma history and number of children (GRADE-CERQual confidence level: low), ${ }^{6,39,46,47}$ For example, one migrant stated, "Every time I would call an advert[isement], I would call asking for a house and they would ask, 'Oh, you have an accent. Where do you come from?' When I told them I am from Africa, well, the apartment was taken." ${ }^{\prime 7}$

\section{Mental health concerns}

The combined impact of the past trauma experienced by migrants and their vulnerable housing situations contributed to mental health concerns, ${ }^{6,36,39,40,50}$ often resulting in sleep problems, loss of appetite and anxiety (GRADE-CERQual confidence level: moderate) ${ }^{37}$ For example, 1 study reported a migrant feeling "seriously stressed" about his homeless status, affecting his mental health. ${ }^{6}$

\section{Poor access to services}

Refugees and other migrants are often unaware of support services and find them difficult to access and navigate (GRADE-CERQual confidence level: moderate). ${ }^{48,51}$ For example, one migrant in the UK stated, "We are going every time to social services. [Asking] Where is [private housing provider]? Where is Refugee Council? We didn't know nothing." 38 Another stated, "It was just presumed that I knew where to go, that I understood the system." ${ }^{40}$ Furthermore, migrants who were unfamiliar with services would not access emergency or transitional accommodation. Some migrants did not identify as homeless, and would not seek out services. ${ }^{40}$

\section{Unsafe housing}

Refugees and other migrants perceived the housing options available to them as unsafe, poorly managed and unaffordable.

\begin{tabular}{|ll|}
\hline Table 1: Components of GRADE-CERQual assessments & \\
\hline Component & \multicolumn{1}{|c|}{ Definition } \\
\hline Methodological limitations & $\begin{array}{l}\text { The extent to which problems were identified in the conduct of the primary studies that contributed to the } \\
\text { evidence for a review finding }\end{array}$ \\
\hline Relevance & $\begin{array}{l}\text { The extent to which the primary studies supporting a review finding are applicable to the context specified in } \\
\text { the review question }\end{array}$ \\
\hline Coherence & $\begin{array}{l}\text { The extent to which a review finding is based on a pattern of data that is similar across multiple individual } \\
\text { studies and/or incorporates (compelling) explanations for any variations across individual studies }\end{array}$ \\
\hline Adequacy of data & $\begin{array}{l}\text { An overall determination of the degree of richness and/or scope of the evidence and of the quantity of data } \\
\text { supporting a review finding }\end{array}$ \\
\hline
\end{tabular}




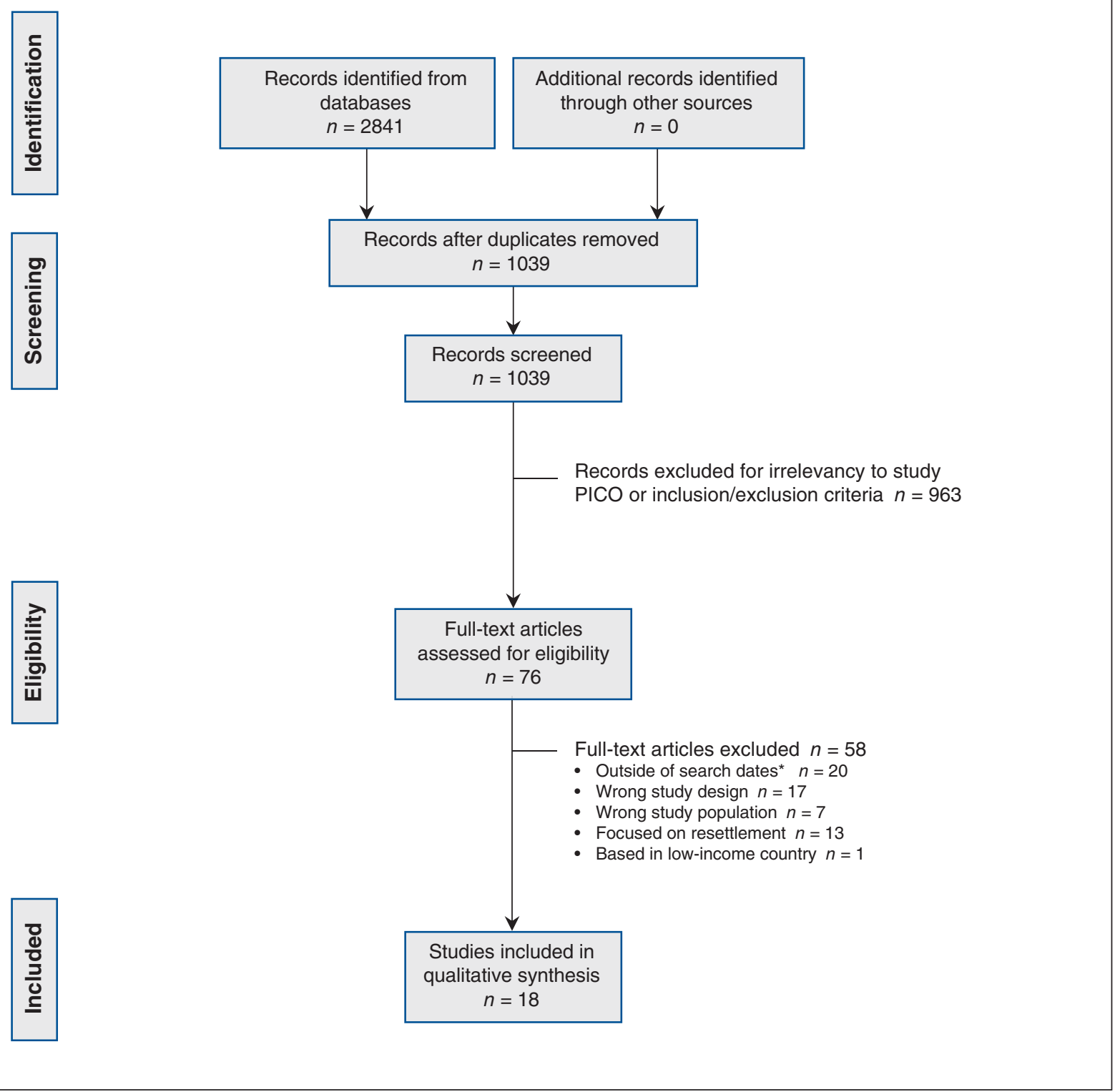

Figure 1: Flow chart based on the Preferred Reporting Items for Systematic Reviews and Meta-Analyses (PRISMA) reporting guidelines. Note: PICO = population, intervention, comparison, outcomes. *We originally searched bibliographical databases from the date of their inception; however, we soon recognized that evidence published since 2007 represents scholarly evolution in the field of migration and global health research. ${ }^{18}$ As a result, we deviated from protocol and restricted date of publication from 2007 onward at the full-text screening phase of the review.

Furthermore, housing programs were often described as strict, controlling, substandard, and in some cases, dangerous, especially by younger populations (GRADE-CERQual confidence level: high)..$^{35,38-40,48}$ In one UK study, several of the respondents described the weaknesses in the National Asylum Support Services housing system as poor quality, overcrowded and lacking effective orientation and services. ${ }^{38}$

\section{Facing family conflict and intercultural tensions}

Several vulnerably housed refugees expressed difficulties learning a new culture, and parents also struggled with the ability of their children to balance a new culture and the culture of their country of origin (GRADE-CERQual confidence level: low). ${ }^{40}$ At times, parents considered their child's acquisition of the English language, Western fashion or new social life as abandonment of their traditional cultural beliefs and values (GRADE-CERQual confidence level: low). ${ }^{39}$ The tension between 2 different cultures often resulted in conflicts and tensions in family support systems (GRADE-CERQual confidence level: low). ${ }^{39}$

\section{Insufficient income assistance}

Refugees and other migrants reported strained finances and inadequate financial support that led to difficulty meeting 
basic needs, housing insecurity and food instability (GRADECERQual confidence level: low). ${ }^{40,45-48}$ In one study, nearly all of the respondents had had trouble finding a new place to live because accommodation was too expensive. ${ }^{47}$

\section{Impact of immigration status}

Compared with status migrants, nonstatus migrants faced substantial barriers, such as limited rights to welfare, prohibition from taking up paid employment and rejection from shelter access (GRADE-CERQual confidence level: low). ${ }^{36,38,45,51}$ Ravnbøl and colleagues ${ }^{51}$ discussed how Danish law prevented migrants from registering as workers in the European Union, and because they did not have a Danish social security number, no one would hire them or rent them a place to live.

\section{Lack of language skills impeding access}

Limited language skills negatively affected accessibility to health and social services for migrants, such as housing programs (GRADE-CERQual confidence level: moderate). ${ }^{51}$ In a study by Couch and colleagues ${ }^{39}$ a young migrant in a rooming house described the challenges of renting with limited English skills, "My English is a problem because I do not always understand the rules of renting a place and may get evicted because I do not understand the rules. Or sometimes notices are placed in the building for people to come together and I can't be involved because I can't read the sign." Mostowska and colleagues considered language the most important resource for migrants to create and expand their social networks beyond their cultural community; ${ }^{43}$ limited language skills can worsen the feeling of being isolated from others (GRADE-CERQual confidence level: moderate). ${ }^{44}$

\section{Limited employment opportunities}

Difficulty obtaining employment was frequently reported among migrants as a barrier to stable and secure housing. Being denied work or meaningful opportunities can inhibit and affect migrants' pride in being active citizens in their resettlement country, as well as affect their personal sense of accomplishment and meaning (GRADE-CERQual confidence level: moderate). ${ }^{37,39,47}$ Dreams of owning a house, studying or working as citizens of a new country were difficult to achieve: "I am so many steps away, miles away from having anything like the Australians have." ${ }^{40}$ Some migrants noted limited personal, family and cultural resources that further exacerbated the ability to find stable and meaningful employment.

\section{Enablers to accessing housing services}

\section{Finding an advocate}

Refugees who sought a culturally familiar, community advocate were able to increase their social capital, which is recognized as the network of social relations that can provide people and groups with access to resources and support (GRADE-CERQual confidence level: high). ${ }^{39-41,47,48}$ Advocates included settlement counsellors and cultural brokers. These advocates were able to help refugees transition out of homelessness by providing social support, a place to stay and other resources. ${ }^{41,48}$ One study reported that when a pregnant woman was faced with impending homelessness, she scanned the public phone directory, looking for Sudanese names from her community. ${ }^{39}$ Similarly, another woman found assistance in housing after approaching a stranger on the street who spoke her first language. ${ }^{47}$

\section{Adopting survival and coping strategies}

Refugees and other migrants who faced insecure housing instability adopted survival and coping strategies that helped them to advocate for resources and develop a sense of belonging in their new community. The survival and coping strategies ranged from faith-based coping to coping using substance use (GRADE-CERQual confidence level: moderate). ${ }^{39-41,46,50}$

\section{Interpretation}

A comprehensive understanding of background characteristics that influence the health and well-being of patients is a prerequisite to delivering equitable health care. ${ }^{52,53}$ Two such characteristics that are hypothesized to increase vulnerability and decrease access to services are homelessness and migration status. ${ }^{4,54}$ We explored the best available qualitative evidence on the enablers and barriers of accessing fundamental health and social services for migrants who found themselves in precarious housing situations.

Our findings suggest that migrants experiencing homelessness often struggle to meet their housing and health needs and to access essential services because of interpersonal racism, limited proficiency with the local language, lack of financial stability and family tensions, leading to worsened mental health conditions. To overcome these barriers, migrants experiencing homelessness often resort to different coping strategies and rely on community advocates to increase their social capital. Even though implementing interpretation services can mitigate linguistic barriers and ensure the provision of equitable care for migrant patients, ${ }^{55,56}$ health care practitioners in Canada need to adopt a more holistic approach to providing care for these populations, one that addresses their housing situation and the barriers that further increase their housing instability and vulnerability, such as family tensions and financial instability.

Migrants described experiencing interpersonal racism when attempting to access health and social services. Xenophobia, racism, and attitudes and behaviours that lead to civic exclusion of others based on a foreign cultural or national identity are upstream factors that produce discrimination and poor health outcomes for migrants. ${ }^{57}$ Interpersonal incidents of racism are an attack on communities, rather than just individuals. ${ }^{58,59}$ Indeed, acts of racism are reflections of historical legacies of colonialism and domination, ${ }^{59}$ which reinforce disempowerment and structural violence. Structural violence describes the social structures that prevent individuals and entire populations from reaching their full potential. ${ }^{60}$ Structural violence continues to serve as a challenge to providing health care for marginalized populations, ${ }^{61,62}$ depriving patients of their right to receive equitable services, and 


\begin{tabular}{|c|c|c|c|c|c|c|}
\hline Study & Country & Design & Population & Intervention & Focus & $\begin{array}{l}\text { CASP risk to } \\
\text { rigour }\end{array}$ \\
\hline Couch $2017^{40}$ & Australia & $\begin{array}{l}\text { Semistructured } \\
\text { interviews }\end{array}$ & $\begin{array}{l}n=24 \text { ( } 10 \\
\text { women and } 14 \\
\text { men) aged } 15 \text { to } \\
24 \text { years }\end{array}$ & $\begin{array}{l}\text { Natural history } \\
\text { study, no } \\
\text { intervention }\end{array}$ & $\begin{array}{l}\text { To open up new } \\
\text { areas of social } \\
\text { enquiry and address } \\
\text { the limited research } \\
\text { focusing on refugee } \\
\text { young people and } \\
\text { homelessness. }\end{array}$ & Low \\
\hline Couch $2011^{39}$ & Australia & $\begin{array}{l}\text { Face-to-face } \\
\text { dialogic } \\
\text { interviews }\end{array}$ & $\begin{array}{l}n=9 \text { ( } 5 \text { women } \\
\text { and } 4 \text { men) aged } \\
19 \text { to } 25 \text { years }\end{array}$ & $\begin{array}{l}\text { Natural history } \\
\text { study, no } \\
\text { intervention }\end{array}$ & $\begin{array}{l}\text { To focus on the } \\
\text { voices of refugee } \\
\text { young people } \\
\text { experiencing } \\
\text { homelessness. }\end{array}$ & Medium \\
\hline $\begin{array}{l}\text { D'Addario et al. } \\
2007^{44}\end{array}$ & Canada & $\begin{array}{l}\text { Semistructured } \\
\text { interviews and } \\
\text { surveys }\end{array}$ & $\begin{array}{l}12 \\
\text { semistructured } \\
\text { interviews, } 36 \\
\text { individual } \\
\text { interviews and } \\
554 \text { surveys }\end{array}$ & $\begin{array}{l}\text { Natural history } \\
\text { study, no } \\
\text { intervention }\end{array}$ & $\begin{array}{l}\text { To evaluate the role of } \\
\text { social capital in } \\
\text { housing trajectories } \\
\text { of immigrants, with } \\
\text { particular attention to } \\
\text { the experiences of } \\
\text { refugee claimants. }\end{array}$ & Low \\
\hline $\begin{array}{l}\text { Flatau et al. } \\
2015^{6}\end{array}$ & Australia & $\begin{array}{l}\text { A cross-sectional } \\
\text { survey, focus } \\
\text { group discussions } \\
\text { and transcent } \\
\text { walks }\end{array}$ & $\begin{array}{l}n=20 \text { ( } 15 \text { men, } \\
4 \text { women and } 1 \\
\text { unknown), } 19 \text { of } \\
\text { whom were aged } \\
\text { between } 22 \text { and } \\
51 \text { years }\end{array}$ & $\begin{array}{l}\text { Natural history } \\
\text { study, no } \\
\text { intervention }\end{array}$ & $\begin{array}{l}\text { To report on the } \\
\text { findings of the } \\
\text { Refugees and } \\
\text { Homelessness } \\
\text { Survey that was } \\
\text { completed with } \\
\text { refugees } \\
\text { experiencing } \\
\text { homelessness or at } \\
\text { risk of homelessness. }\end{array}$ & Low \\
\hline Im $2011^{37}$ & US & $\begin{array}{l}\text { In-depth } \\
\text { individual } \\
\text { interviews }\end{array}$ & $\begin{array}{l}n=26 \text { ( } 4 \text { men } \\
\text { and } 22 \text { women), } \\
\text { mean age } 36.6 \\
\text { years }\end{array}$ & $\begin{array}{l}\text { Natural history } \\
\text { study, no } \\
\text { intervention }\end{array}$ & $\begin{array}{l}\text { To explore the mental } \\
\text { health of refugee } \\
\text { families in the } \\
\text { socioecological } \\
\text { contexts of } \\
\text { displacement and } \\
\text { homelessness, and } \\
\text { to investigate } \\
\text { stressors and coping } \\
\text { in relation to } \\
\text { transition of } \\
\text { resources, including } \\
\text { social capital of } \\
\text { refugee families. }\end{array}$ & Low \\
\hline
\end{tabular}




\begin{tabular}{|c|c|c|c|c|c|c|}
\hline Study & Country & Design & Population & Intervention & Focus & $\begin{array}{l}\text { CASP risk to } \\
\text { rigour }\end{array}$ \\
\hline Kissoon $2010^{36}$ & Canada & Interviews & $\begin{array}{l}n=34 \text { migrants } \\
\text { (18 women, } 16 \\
\text { men), } 27 \text { key } \\
\text { informants from } \\
\text { nongovernmental } \\
\text { organization, } \\
\text { legal and health } \\
\text { sectors. }\end{array}$ & $\begin{array}{l}\text { Natural history } \\
\text { study, no } \\
\text { intervention }\end{array}$ & $\begin{array}{l}\text { To focus on the refugee } \\
\text { determination system } \\
\text { to draw attention to the } \\
\text { intersection of illegality } \\
\text { and vulnerability to } \\
\text { persecution, and to } \\
\text { identify the } \\
\text { characteristics and } \\
\text { homelessness } \\
\text { experiences of } \\
\text { nonstatus or } \\
\text { undocumented migrant } \\
\text { participants in } \\
\text { Vancouver and Toronto. }\end{array}$ & Medium \\
\hline $\begin{array}{l}\text { Mostowska } \\
2013^{42}\end{array}$ & Norway & $\begin{array}{l}\text { Narrative } \\
\text { interviews and } \\
\text { informal } \\
\text { conversations }\end{array}$ & $\begin{array}{l}n=40 \text { aged from } \\
23 \text { to } 62 \text { years, } \\
\text { most between } \\
35-55 \text { years }\end{array}$ & $\begin{array}{l}\text { Natural history } \\
\text { study, no } \\
\text { intervention }\end{array}$ & $\begin{array}{l}\text { To discuss the results } \\
\text { of fieldwork conducted } \\
\text { among migrants of } \\
\text { Polish descent } \\
\text { experiencing } \\
\text { homelessness in Oslo, } \\
\text { Norway, with focus on } \\
\text { the social networks } \\
\text { that are a part of the } \\
\text { migrants' social capital. }\end{array}$ & Medium \\
\hline $\begin{array}{l}\text { Mostowska } \\
2012^{43}\end{array}$ & Belgium & $\begin{array}{l}\text { Field notes, } \\
\text { informal } \\
\text { conversations } \\
\text { and individual } \\
\text { interviews }\end{array}$ & $\begin{array}{l}n=45 \text { ( } 6 \text { women, } \\
39 \text { men) people } \\
\text { of Polish descent } \\
\text { who had been } \\
\text { sleeping rough or } \\
\text { reported an } \\
\text { episode of rough } \\
\text { sleeping in the } \\
\text { recent past. } \\
\text { Thirteen of the } \\
\text { men were older } \\
\text { than } 55 \text { years, } \\
\text { and } 16 \text { people } \\
\text { were younger } \\
\text { than } 35 \text { years }\end{array}$ & $\begin{array}{l}\text { Natural history } \\
\text { study, no } \\
\text { intervention }\end{array}$ & $\begin{array}{l}\text { To acknowledge } \\
\text { homelessness among } \\
\text { migrants of Polish } \\
\text { descent in Brussels } \\
\text { and analyze their } \\
\text { narratives using Julian } \\
\text { Wolpert's concept of } \\
\text { "place utility" to confront } \\
\text { the way they talk about } \\
\text { their adaptation to the } \\
\text { environment with the } \\
\text { risks and opportunities } \\
\text { they attach to staying in } \\
\text { Brussels and to their } \\
\text { possible return } \\
\text { migration to Poland. }\end{array}$ & High \\
\hline $\begin{array}{l}\text { Paradis et al. } \\
2008^{45}\end{array}$ & Canada & Interviews & $\begin{array}{l}n=91 \text { women- } \\
\text { led homeless } \\
\text { families }\end{array}$ & $\begin{array}{l}\text { Immigrant and } \\
\text { refugee families v. } \\
\text { Canadian-born } \\
\text { families } \\
\text { experiencing } \\
\text { homelessness. } \\
\text { Each woman was } \\
\text { interviewed } 3 \\
\text { times over the } \\
\text { course of a year. }\end{array}$ & $\begin{array}{l}\text { To understand } \\
\text { homelessness among } \\
\text { immigrant and refugee } \\
\text { families to improve } \\
\text { public policy and } \\
\text { programs for these } \\
\text { families. }\end{array}$ & Medium \\
\hline $\begin{array}{l}\text { Sjollema et al. } \\
2012^{46}\end{array}$ & Canada & $\begin{array}{l}\text { Semistructured } \\
\text { interviews }\end{array}$ & $\begin{array}{l}n=26 \text { women, } \\
\text { most aged } \\
\text { between } 20 \text { to } 40 \\
\text { years }\end{array}$ & $\begin{array}{l}\text { Natural history } \\
\text { study, no } \\
\text { intervention }\end{array}$ & $\begin{array}{l}\text { To provide a context } \\
\text { for understanding } \\
\text { homelessness among } \\
\text { newcomer women } \\
\text { and to summarize the } \\
\text { history of the found } \\
\text { poem in a variety of } \\
\text { disciplines with an } \\
\text { emphasis on "social } \\
\text { work and the arts" } \\
\text { context. }\end{array}$ & Medium \\
\hline
\end{tabular}


Table 2 (part 3 of 3): Characteristics of included studies

\begin{tabular}{|c|c|c|c|c|c|c|}
\hline Study & Country & Design & Population & Intervention & Focus & $\begin{array}{l}\text { CASP risk to } \\
\text { rigour }\end{array}$ \\
\hline $\begin{array}{l}\text { Walsh et al. } \\
2015^{47}\end{array}$ & Canada & $\begin{array}{l}\text { Semistructured, } \\
\text { open-ended } \\
\text { interviews }\end{array}$ & $\begin{array}{l}n=26 \text { women } \\
\text { aged from 22-64 } \\
\text { years }\end{array}$ & $\begin{array}{l}\text { Natural history } \\
\text { study, no } \\
\text { intervention }\end{array}$ & $\begin{array}{l}\text { To explore housing } \\
\text { insecurity among } \\
\text { newcomer women to } \\
\text { Montréal, Canada. }\end{array}$ & Low \\
\hline $\begin{array}{l}\text { Polillo and } \\
\text { Sylvestre } \\
2019^{48}\end{array}$ & Canada & $\begin{array}{l}\text { In-depth } \\
\text { interviews }\end{array}$ & $\begin{array}{l}n=36 \text { ( } 23 \\
\text { foreign-born } \\
\text { families, } 13 \\
\text { Canadian-born } \\
\text { families). Mean } \\
\text { age for the } \\
\text { foreign-born } \\
\text { sample was } \\
38.27 \text { years (SD } \\
9.57) ; 73.9 \% \text { of } \\
\text { the foreign-born } \\
\text { sample are } \\
\text { women }\end{array}$ & $\begin{array}{l}\text { Foreign-born v. } \\
\text { Canadian-born } \\
\text { families }\end{array}$ & $\begin{array}{l}\text { To investigate the } \\
\text { experiences of } \\
\text { foreign-born families } \\
\text { in the } 4 \text { years before } \\
\text { becoming homeless. }\end{array}$ & Low \\
\hline $\begin{array}{l}\text { Polillo et al. } \\
2017^{49}\end{array}$ & Canada & $\begin{array}{l}\text { Interviews with } \\
\text { adult heads of } \\
\text { families }\end{array}$ & $\begin{array}{l}n=75 \\
\text { (Canadian-born } \\
\text { interviewees: } 6 \\
\text { men, } 20 \text { women, } \\
\text { mean age } 33.8 \\
\text { years; foreign- } \\
\text { born: } 14 \text { men, } 34 \\
\text { women, mean } \\
\text { age } 36.8 \text { years) }\end{array}$ & $\begin{array}{l}\text { Foreign-born v. } \\
\text { Canadian-born } \\
\text { people }\end{array}$ & $\begin{array}{l}\text { To evaluate the health } \\
\text { of foreign-born } \\
\text { families staying in the } \\
\text { emergency shelter } \\
\text { system in Ottawa, and } \\
\text { to compare their } \\
\text { experiences to } \\
\text { Canadian-born } \\
\text { families who are also } \\
\text { living in shelters. }\end{array}$ & Low \\
\hline $\begin{array}{l}\text { St-Arnault and } \\
\text { Merali } 2018^{41}\end{array}$ & Canada & Interviews & $\begin{array}{l}n=19 \text { ( } 11 \\
\text { women, } 8 \text { men), } \\
\text { aged } 29 \text { to } 73 \\
\text { years, mean age } \\
39 \text { years }\end{array}$ & $\begin{array}{l}\text { Natural history } \\
\text { study, no } \\
\text { intervention }\end{array}$ & $\begin{array}{l}\text { To investigate } \\
\text { pathways out of } \\
\text { homelessness among } \\
\text { a mixed sample of } \\
\text { adult refugees who } \\
\text { had experienced } \\
\text { absolute or relative } \\
\text { homelessness after } \\
\text { their arrival in Canada, } \\
\text { but who eventually } \\
\text { became adequately } \\
\text { settled in one of } \\
\text { Canada's large urban } \\
\text { centres in Alberta. }\end{array}$ & Low \\
\hline $\begin{array}{l}\text { Ravnbøl } \\
2017^{51}\end{array}$ & Denmark & $\begin{array}{l}\text { Semistructured } \\
\text { interviews }\end{array}$ & $n=40$ & $\begin{array}{l}\text { Natural history } \\
\text { study, no } \\
\text { intervention }\end{array}$ & $\begin{array}{l}\text { To address health } \\
\text { concerns and access } \\
\text { to health services } \\
\text { among migrants of } \\
\text { Roma descent in the } \\
\text { European Union, from } \\
\text { a perspective of } \\
\text { Romanian Roma who } \\
\text { live in homelessness } \\
\text { in Copenhagen. }\end{array}$ & Medium \\
\hline $\begin{array}{l}\text { Hanley et al. } \\
2018^{50}\end{array}$ & Canada & $\begin{array}{l}\text { Semistructured, } \\
\text { open-ended } \\
\text { interviews }\end{array}$ & $\begin{array}{l}n=26 \text { women } \\
\text { aged } 20 \text { to } 65 \\
\text { years }\end{array}$ & $\begin{array}{l}\text { Natural history } \\
\text { study, no } \\
\text { intervention }\end{array}$ & $\begin{array}{l}\text { To explore how health } \\
\text { intersects with the } \\
\text { experience of housing } \\
\text { insecurity and } \\
\text { homelessness, } \\
\text { specifically for migrant } \\
\text { women. }\end{array}$ & Low \\
\hline
\end{tabular}


increasing the social gradient of how beneficial such services tend to be. ${ }^{53}$ Even though discrimination has been found to sever trustworthy connections between the general homeless population and their health care providers, ${ }^{63}$ our findings suggest that this problem is further aggravated when patients who are homeless also have a migration history. In Canada, primary health care practitioners can effectively address their patients' experiences of interpersonal racism by employing trauma-informed care in its core values and principles. ${ }^{64}$

Past trauma was found to worsen the mental health conditions of refugees and other migrants. The literature is abundant with evidence linking premigration and migration exposures of trauma and violence to the initiation or exacerbation of common mental health conditions, such as major depressive disorders, generalized anxiety and posttraumatic stress disorders. ${ }^{14,65}$ In Canada, the literature highlights a trend of limited access and uptake of mental health services by different migrant populations. ${ }^{66,67}$ With the scarcity of mental health screening initiatives, ${ }^{68}$ and the discontinuity of mental health care after resettlement, ${ }^{69}$ migrants find themselves in need of scaled-up mental health services that could be delivered in their communities. ${ }^{70}$

Moreover, homelessness after resettlement was a fundamental component that worsened many mental health conditions among migrants. This finding suggests that homelessness is not only the consequence of poor mental health, but also a predictor of poor mental health. Primary health care

Table 3 (part 1 of 2): Summary of findings

\begin{tabular}{|c|c|c|c|}
\hline \multirow[b]{2}{*}{$\begin{array}{l}\text { Framework } \\
\text { level }\end{array}$} & \multirow[b]{2}{*}{ Key findings } & \multicolumn{2}{|r|}{ GRADE-CERQual assessment } \\
\hline & & $\begin{array}{l}\text { Confidence in } \\
\text { the evidence }\end{array}$ & Explanation \\
\hline Discrimination & $\begin{array}{l}\text { Systemic racism: Refugees experienced individual } \\
\text { and systemic racism, which exacerbated housing } \\
\text { instability. Many refugees felt they were turned away } \\
\text { from housing and emergency shelters because of their } \\
\text { ethnicity, use of welfare cheques, history of trauma, } \\
\text { language of origin, temporary resident status and the } \\
\text { presence of children. }\end{array}$ & Low & $\begin{array}{l}\text { Moderate concerns for methodological } \\
\text { limitations and adequacy, and no-to-minor } \\
\text { concerns for coherence and relevance. }\end{array}$ \\
\hline Mental health & $\begin{array}{l}\text { Mental health concerns: Lived experience of trauma } \\
\text { and housing insecurity resulted in persistent } \\
\text { psychological distress and mental health concerns. }\end{array}$ & Moderate & $\begin{array}{l}\text { Very minor concerns for methodological } \\
\text { limitations, no-to-very minor concerns for } \\
\text { coherence, relevance and adequacy. }\end{array}$ \\
\hline $\begin{array}{l}\text { Social } \\
\text { networks and } \\
\text { support }\end{array}$ & $\begin{array}{l}\text { Finding an advocate: Refugees who sought a } \\
\text { culturally familiar community advocate were able to } \\
\text { increase their social capital. Advocates included } \\
\text { settlement counsellors and cultural brokers. These } \\
\text { advocates were able to help refugees transition out of } \\
\text { homelessness by providing social support, a place to } \\
\text { stay and other resources. }\end{array}$ & High & $\begin{array}{l}\text { Minor concerns for methodological } \\
\text { limitations, no-to-very minor concerns for } \\
\text { coherence, relevance and adequacy. }\end{array}$ \\
\hline \multirow[t]{2}{*}{$\begin{array}{l}\text { Services: } \\
\text { health and } \\
\text { housing }\end{array}$} & $\begin{array}{l}\text { Poor access to services: Refugees and other } \\
\text { migrants, particularly undocumented migrants, failed } \\
\text { asylum seekers and those with humanitarian protection, } \\
\text { are often unaware of support services and find them } \\
\text { difficult to access and navigate. }\end{array}$ & Moderate & $\begin{array}{l}\text { Minor concerns for methodological } \\
\text { limitations, no-to-very minor concerns for } \\
\text { coherence, relevance and adequacy. }\end{array}$ \\
\hline & $\begin{array}{l}\text { Unsafe housing: Refugees and other migrants } \\
\text { perceived the housing options available to them as } \\
\text { unsafe, poorly managed and unaffordable. }\end{array}$ & High & $\begin{array}{l}\text { Minor concerns for methodological } \\
\text { limitations, very minor-to-minor concerns for } \\
\text { relevance and no-to-very minor concerns } \\
\text { for coherence and adequacy. }\end{array}$ \\
\hline $\begin{array}{l}\text { Family } \\
\text { structure }\end{array}$ & $\begin{array}{l}\text { Facing a family separation: Several vulnerably housed } \\
\text { refugees expressed difficulties learning a new culture, } \\
\text { and parents struggled with the ability of their children to } \\
\text { balance a new culture and the culture of their country of } \\
\text { origin. This family conflict led to a loss of family support, } \\
\text { which is a protective factor against homelessness. }\end{array}$ & Low & $\begin{array}{l}\text { Moderate concerns for methodological } \\
\text { limitations and relevance, no-to-very minor } \\
\text { concerns for coherence and adequacy. }\end{array}$ \\
\hline Income & $\begin{array}{l}\text { Insufficient income assistance: Refugees and other } \\
\text { migrants reported strained finances and inadequate } \\
\text { financial support that led to difficulty meeting basic } \\
\text { needs, housing insecurity and food instability. }\end{array}$ & Low & $\begin{array}{l}\text { Moderate concerns for methodological } \\
\text { limitations and relevance, no-to-very minor } \\
\text { concerns for coherence and adequacy. }\end{array}$ \\
\hline $\begin{array}{l}\text { Immigration } \\
\text { status }\end{array}$ & $\begin{array}{l}\text { Impact of immigration status: Compared with status } \\
\text { migrants, nonstatus migrants faced substantial barriers, } \\
\text { such as limited rights to welfare, prohibition from taking } \\
\text { up paid employment and rejection from shelter access. }\end{array}$ & Low & $\begin{array}{l}\text { Serious concerns for methodological } \\
\text { limitations, moderate concerns for } \\
\text { relevance and no-to-very minor concerns } \\
\text { for coherence and adequacy. }\end{array}$ \\
\hline
\end{tabular}




\begin{tabular}{|c|c|c|c|}
\hline \multirow[b]{2}{*}{$\begin{array}{l}\text { Framework } \\
\text { level }\end{array}$} & \multirow[b]{2}{*}{ Key findings } & \multicolumn{2}{|r|}{ GRADE-CERQual assessment } \\
\hline & & $\begin{array}{l}\text { Confidence in } \\
\text { the evidence }\end{array}$ & Explanation \\
\hline Language & $\begin{array}{l}\text { Lack of language skills impeding access: Limited } \\
\text { language skills among refugees impeded their ability to } \\
\text { access most services, including housing services, and } \\
\text { limited their social capital and connections beyond their } \\
\text { original community. }\end{array}$ & Moderate & $\begin{array}{l}\text { Moderate concerns for methodological } \\
\text { limitations, no-to-minor concerns for } \\
\text { coherence, adequacy and relevance. }\end{array}$ \\
\hline Outlier & $\begin{array}{l}\text { Adopting survival and coping strategies: } \\
\text { Refugees and other migrants who faced insecure } \\
\text { housing instability adopted survival and coping } \\
\text { strategies that helped them to advocate for } \\
\text { resources and develop a sense of belonging in their } \\
\text { new community. }\end{array}$ & Moderate & $\begin{array}{l}\text { Moderate concerns for relevance, no-to- } \\
\text { minor concerns for coherence, relevance } \\
\text { and adequacy. }\end{array}$ \\
\hline
\end{tabular}

practitioners in Canada now have an evidence-based guideline to address homelessness as the root for many morbidities and to initiate care for patients experiencing homelessness, including migrants, using upstream and longitudinal interventions. ${ }^{71}$

It is important to develop and evaluate public health responses for migrants who are homeless or vulnerably housed, especially undocumented migrants. Advances in universal access to health services ${ }^{72}$ and social accountability in medical schools ${ }^{73}$ could be matched with policy changes to ensure health equity for homeless migrants. Public health could play a role in raising awareness of these priority populations and developing programs and policies that address access and discrimination barriers, such as antiracist housing policies, migrant-sensitive mental health supports in shelters and migrant-specific shelters. Indeed, public health research can deepen our understanding of the values, attitudes and perceptions of migrants regarding housing, and can have a role in improving outcomes of the social determinants of health.

We evaluated the enablers and barriers of accessing health and social services among a population with lived experience of homelessness. We followed systematic and transparent review methodology to ensure we identified the best available evidence on this phenomenon. As a result, we included studies of vulnerable migrants from diverse geographic regions around the world. Furthermore, we used the GRADE-CERQual methodology to rate the confidence in our findings.

\section{Limitations}

We did not use a Peer Review of Electronic Search Strategies (PRESS) ${ }^{74}$ which could have guided and improved the search strategy. We did not conduct a grey literature search, nor did we search any reference lists. A protocol deviation is also further detailed in Appendix 7, available at www.cmajopen.ca/ content/9/2/E681/suppl/DC1. Furthermore, our findings are constrained to the data provided by the interviews and participants within the published primary studies. For example, most participants spoke English, and we recognize that language is an important additional barrier to resources.
Only a small number of participants were undocumented migrants, an important subgroup of this vulnerable population. More subgroup analyses, such as from youth or the recent Syrian refugees, would be important to better understand these specific populations in the future. Most included articles did not describe in detail the relationship between the researcher and the participant which, if not addressed appropriately, could introduce concerns of interviewer and social desirability biases and jeopardize the trustworthiness of qualitative evidence from primary studies. Lastly, we tried to ensure that our findings and considerations were applicable to the Canadian context, which required contextualization and judgments on the relevance of included studies conducted outside of Canada. This process, however, was not always feasible given reporting limitations on the primary-study level.

\section{Conclusion}

We highlighted the challenges that refugees and other migrants face after resettlement and when experiencing homelessness. Discrimination and xenophobia were recurrent themes described as both a cause and a consequence of unsafe and insecure housing. An important finding was the limited research available on undocumented migrants experiencing homelessness. Vulnerable housing was often linked to family separation, poor access to services and limited income and employment. Migrants may also face language, cultural and immigration status barriers, and they may benefit from field advocates and personal survival strategies. These findings warrant physician vigilance and public health responses.

\section{References}

1. McAuliffe M, Ruhs M, editors. World Migration Report 2020. Geneva: International Organization for Migration; 2019:1-477. Available: www.un.org/sites/ un2.un.org/files/wmr_2020.pdf (accessed 2020 Nov. 16).

2. McAuliffe M, Ruhs M, editors. World Migration Report 2018. Geneva: International Organization for Migration; 2017:1-347. Available: https://publications. iom.int/system/files/pdf/wmr_2018_en.pdf (accessed 2020 Nov. 16).

3. Gushulak BD, Pottie K, Roberts JH, et al.; Canadian Collaboration for Immigrant and Refugee Health. Migration and health in Canada: health in the global village. CMA7 2011;183:E952-8. 
4. Pleace N. Immigration and homelessness. In: O'Sullivan E, editor. Homelessness Research in Europe: Festschrift for Bill Edgar and Foe Doherty. Brussels (Belgium): FEANTSA; 2011;143-62.

5. Fitzpatrick S, Johnsen S, Bramley G. Multiple exclusion homelessness amongst migrants in the UK. Eur 7 Homelessness 2012;6:31-58.

6. Flatau P, Smith J, Carson G, et al. The housing and homelessness journeys of refugees in Australia. AHURI Final Report No. 256. In: Badenhorst A. Melbourne (AU): Australian Housing and Urban Research Institute; 2015:1-110. Available: www.ahuri.edu.au/publications/projects/p82015 (accessed 2017 Sept. 1).

7. Keung N. Refugee system in need of overhaul, report says. Toronto Star 2018 June 26. Available: www.thestar.com/news/gta/2018/06/26/refugee-systemin-need-of-overhaul-report-says.html (accessed 2018 Aug. 1).

8. Grant T. Wave of asylum seekers floods Toronto's shelters. The Globe and Mail 2018 June 20, updated 2018 June 22. Available: www.theglobeandmail.com/ canada/article-in-toronto-asylum-seekers-hope-to-carve-out-a-new-home/ (accessed 2018 Aug. 1).

9. Gaetz S, Barr C, Friesen A, et al. Canadian definition of homelessness. Toronto: Canadian Observatory on Homelessness; 2012. Available: www.homelesshub. $\mathrm{ca} /$ resource/canadian-definition-homelessness (accessed 2018 June 17).

10. Pottie K, Martin JP, Cornish S, et al. Access to healthcare for the most vulnerable migrants: a humanitarian crisis. Confl Health 2015;9:16.

11. Asanin J, Wilson K. "I spent nine years looking for a doctor": exploring access to health care among immigrants in Mississauga, Ontario, Canada. Soc Sci Med 2008;66:1271-83.

12. Hwang SW, Wilkins R, Tjepkema M, et al. Mortality among residents of shelters, rooming houses, and hotels in Canada: 11 year follow-up study. BM7 2009;339:b4036.

13. Lee TC, Hanlon JG, Ben-David J, et al. Risk factors for cardiovascular disease in homeless adults. Circulation 2005;111:2629-35.

14. Kirmayer LJ, Narasiah L, Munoz M, et al.; Canadian Collaboration for Immigrant and Refugee Health (CCIRH). Common mental health problems in immigrants and refugees: general approach in primary care. CMAF 2011;183:E959-67.

15. Pottie K, Greenaway C, Feightner J, et al.; Canadian Collaboration for Immigrant and Refugee Health. Evidence-based clinical guidelines for immigrants and refugees. CMA7 2011;183:E824-925.

16. Goel R, Bloch G, Caulford P. Waiting for care: effects of Ontario's 3-month waiting period for OHIP on landed immigrants. Can Fam Physician 2013;59:e269-75.

17. Swinkels H, Pottie K, Tugwell P, et al.; Canadian Collaboration for Immigrant and Refugee Health (CCIRH). Development of guidelines for recently arrived immigrants and refugees to Canada: Delphi consensus on selecting preventable and treatable conditions. CMA7 2011;183:E928-32.

18. Sweileh WM, Wickramage K, Pottie K, et al. Bibliometric analysis of global migration health research in peer-reviewed literature (2000-2016). BMC Public Health 2018; 18:777.

19. Kaur H, Mathew C, Mayhew A, et al. Understanding the health and homeless experiences of vulnerably housed refugees and other migrant populations: a systematic review using GRADE CERQual. Prospero 2018 CRD42018071568. National Institute for Health Research; 2017. Available: www.crd.york.ac.uk/ prospero/display_record.php?RecordID=71568 (accessed 2020 Mar. 4).

20. Moher D, Shamseer L, Clarke M, et al. PRISMA-P Group. Preferred reporting items for systematic review and meta-analysis protocols (PRISMA-P) 2015 statement. Syst Rev 2015;4:1.

21. World Bank country and lending group. Washington (DC): The World Bank. Available: https://datahelpdesk.worldbank.org/knowledgebase/articles/906519 -world-bank-country-and-lending-groups (accessed 2020 Mar. 4).

22. Brell C, Dustmann C, Preston I. The labor market integration of refugee migrants in high-income countries. 7 Econ Perspect 2020;34:94-121.

23. Fazel S, Geddes JR, Kushel M. The health of homeless people in highincome countries: descriptive epidemiology, health consequences, and clinical and policy recommendations. Lancet 2014;384:1529-40.

24. Brandenberger J, Tylleskär T, Sontag K, et al. A systematic literature review of reported challenges in health care delivery to migrants and refugees in high-income countries - the 3C model. BMC Public Health 2019;19:755.

25. CASP checklists. Oxford (UK): Critical Appraisal Skills Programme (CASP). Available: https://casp-uk.net/casp-tools-checklists/ (accessed 2017 Dec. 1).

26. Carroll C, Booth A, Leaviss J, et al. "Best fit" framework synthesis: refining the method. BMC Med Res Methodol 2013;13:37.

27. Booth A, Carroll C. How to build up the actionable knowledge base: the role of "best fit" framework synthesis for studies of improvement in healthcare. BM7 Qual Saf 2015;24:700-8.

28. Gale NK, Heath G, Cameron E, et al. Using the framework method for the analysis of qualitative data in multi-disciplinary health research. $B M C \mathrm{Med}$ Res Methodol 2013;13:117.

29. Spencer L, Ritchie J. Qualitative data analysis for applied policy research. In: Analyzing Qualitative Data. Abingdon: Routledge; 1994.

30. Bierman AS, Johns A, Hyndman B, et al. Social determinants of health and populations at risk. In: Bierman AS, editor. Project for an Ontario Women's Health Evidenced-Based Report: Volume 2. Toronto: The POWER Study, Keenan Research Centre in the Li Ka Shing Knowledge Institute, St. Michael's Hospital; 2012.
31. Agnew V. Racialized migrant women in Canada: essays on health, violence and equity. Toronto: University of Toronto Press; 2009. Available: https://utoron topress.com/ca/racialized-migrant-women-in-canada-4 (accessed 2017 July 1).

32. Lewin S, Glenton C, Munthe-Kaas H, et al. Using qualitative evidence in decision making for health and social interventions: an approach to assess confidence in findings from qualitative evidence syntheses (GRADE-CERQual). PLoS Med 2015;12:e1001895.

33. Lewin S, Booth A, Glenton C, et al. Applying GRADE-CERQual to qualitative evidence synthesis findings: introduction to the series. Implement Si 2018;13(Suppl 1):2.

34. Schünemann H, Brozek J, Guyatt $\mathrm{G}$, et al. GRADE handbook for grading quality of evidence and strength of recommendations. Version 3.2. GRADE Working Group; updated 2013.

35. Couch J. On their own: perceptions of services by homeless young refugees. Developing Practice: The Child, Youth and Family Work fournal 2012;(31):19-28.

36. Kissoon P. An uncertain home: refugee protection, illegal immigration status, and their effects on migrants' housing stability in Vancouver and Toronto. Canadian Issues 2010;(Autumn):64-7. Available: https://search.proquest.com/ openview/6b1915ffff359e7e96dc30b86274b798/1?pqorigsite $=$ gscholar \&cbl $=43874($ accessed 2017 Sept. 1$)$.

37. Im H. A social ecology of stress and coping among homeless refugee families [dissertation]. Minneapolis (MN): University of Minnesota Digital Conservancy; 2011. Available: https://conservancy.umn.edu/handle/11299/116170 (accessed 2017 Sept. 1).

38. Dwyer P, Brown D. Accommodating 'others'?: Housing dispersed, forced migrants in the UK. 7 Soc Welf Fam Law 2008;30:203-18.

39. Couch J. "My life just went zig zag": Refugee young people and homelessness. Youth Stud Aust 2011;30:22-32.

40. Couch J. 'Neither here nor there': refugee young people and homelessness in Australia. Children and Youth Services Review 2017;74:1-7.

41. St. Arnault D, Merali N. Pathways for refugees' descent into homelessness in Edmonton, Alberta: the urgent need for policy and procedural change. 7 Int Migr Integr 2019;20:1161-79.

42. Mostowska M. Homelessness abroad: "place utility" in the narratives of the Polish homeless in Brussels. Int Migr 2014;52:118-29.

43. Mostowska M. Migration and Homelessness: The Social Networks of Homeless Poles in Oslo. F Ethn Migr Stud 2013;39:1125-40.

44. d'Addario S, Hiebert D, Sherrell K. Restricted access: the role of social capital in mitigating absolute homelessness among immigrants and refugees in the GVRD. Refuge. Canada's Fournal on Refugees 2007;24:107-15.

45. Paradis E, Novac S, Sarty M, et al. Better off in a shelter? A year of homelessness housing among status immigrant, non-status migrant, Canadian-born families. Toronto: Canadian Observatory on Homelessness; 2009. Available: www.homelesshub.ca/resource/42-better-shelter-year-homelessness-housing -among-status-immigrant-non-status-migrant (accessed 2017 Sept. 1).

46. Sjollema SD, Hordyk S, Walsh CA, et al. Found poetry: finding home A qualitative study of homeless immigrant women. 7 Poetry Ther 2012; 25:205-17

47. Walsh CA, Hanley J, Ives N, et al. Exploring the experiences of newcomer women with insecure housing in Montréal Canada. 7 Int Migr Integr 2016; 17:887-904.

48. Polillo A, Sylvestre J. An exploratory study of the pathways into homelessness among of foreign-born and Canadian-born families: a timeline mapping approach. Fournal of Social Distress and Homelessness 2019 Dec. 19 [Epub ahead of print]. doi: 10.1080/10530789.2019.1705518.

49. Polillo A, Kerman N, Sylvestre J, et al. The health of foreign-born homeless families living in the family shelter system. Int 7 Migr Health Soc Care 2018;14:260-8.

50. Hanley J, Ives N, Lenet J, et al. Migrant women's health and housing insecurity: an intersectional analysis. Int 7 Migr Health Soc Care 2019;15:90-106.

51. Ravnbøl CI. Doubling syndemics: ethnographic accounts of the health situation of homeless Romanian Roma in Copenhagen. Health Hum Rights 2017;19:73-88.

52. Dans AL, Dans LF, Agoritsas T, et al. Applying results to individual patients. In: Users' Guides to the Medical Literature: A Manual for Evidence-Based Clinical Practice. 3rd ed. New York McGraw-Hill Companies; 2008:273-89.

53. O'Neill J, Tabish H, Welch V, et al. Applying an equity lens to interventions: using PROGRESS ensures consideration of socially stratifying factors to illuminate inequities in health. 7 Clin Epidemiol 2014;67:56-64.

54. Mostowska M. 'We shouldn't but we do ...': framing the strategies for helping homeless EU migrants in Copenhagen and Dublin. Br 7 Soc Work 2014;44(Suppl 1):i18-34.

55. Pottie K, Batista R, Mayhew M, et al. Improving delivery of primary care for vulnerable migrants: Delphi consensus to prioritize innovative practice strategies. Can Fam Physician 2014;60:e32-40.

56. Saad A, Pottie K, Chiu CP. Refugees and internally displaced populations. In: WHO Guidance on Research Methods for Health Emergency and Disaster Risk Management. Geneva: World Health Organization.

57. Suleman S, Garber KD, Rutkow L. Xenophobia as a determinant of health: an integrative review. 7 Public Health Policy 2018;39:407-23.

58. Modood T, Berthoud R, Lakey J, et al. Ethnic minorities in Britain: diversity and disadvantage. PSI report 843. London (UK): Policy Studies Institute; 1997. 
59. Nazroo JY, Bhui KS, Rhodes J. Where next for understanding race/ethnic inequalities in severe mental illness? Structural, interpersonal and institutional racism. Sociol Health Illn 2020;42:262-76.

60. Farmer PE, Nizeye B, Stulac S, et al. Structural violence and clinical medicine. PLoS Med 2006;3:e449.

61. Larchanché S. Intangible obstacles: health implications of stigmatization, structural violence, and fear among undocumented immigrants in France. Soc Sci Med 2012;74:858-63.

62. Konczal L, Varga L. Structural violence and compassionate compatriots: immigrant health care in South Florida. Ethn Racial Stud 2012;35:88-103.

63. Magwood O, Leki VY, Kpade V, et al. Common trust and personal safety issues: a systematic review on the acceptability of health and social interventions for persons with lived experience of homelessness. PLoS One 2019; 14:e0226306.

64. Purkey E, Patel R, Phillips SP. Trauma-informed care: better care for everyone. Can Fam Physician 2018;64:170-2.

65. Steel Z, Chey T, Silove D, et al. Association of torture and other potentially traumatic events with mental health outcomes among populations exposed to mass conflict and displacement: a systematic review and meta-analysis. $7 A M A$ 2009;302:537-49.

66. Fenta H, Hyman I, Noh S. Mental health service utilization by Ethiopian immigrants and refugees in Toronto. 7 Nerv Ment Dis 2006;194:925-34.

67. Whitley R, Kirmayer LJ, Groleau D. Understanding immigrants' reluctance to use mental health services: a qualitative study from Montreal. Can 7 Psychiatry 2006;51:205-9.

68. Shannon P, Im H, Becher E, et al. Screening for war trauma, torture, and mental health symptoms among newly arrived refugees: a national survey of U.S. refugee health coordinators. F Immigr Refug Stud 2012;10:380-94.

69. Shannon PJ, Wieling E, Simmelink-McCleary J, et al. Beyond Stigma: Barriers to Discussing Mental Health in Refugee Populations. 7 Loss Trauma 2015;20:281-96

70. Sijbrandij M, Acarturk C, Bird M, et al. Strengthening mental health care systems for Syrian refugees in Europe and the Middle East: integrating scalable psychological interventions in eight countries. Eur 7 Psychotraumatol 2017;8(Suppl 2):1388102.

71. Pottie K, Kendall CE, Aubry T, et al. Clinical guideline for homeless and vulnerably housed people, and people with lived homelessness experience. CMA7 2020;192:E240-54.

72. Legido-Quigley H, Pocock N, Tan ST, et al. Healthcare is not universal if undocumented migrants are excluded. BM7 2019;366:14160.

73. Malena C, Forster R, Singh J. An introduction to the concept and emerging practice. In: Social Development Papers: Participation and Civic Engagement. Paper No. 76. Washington (DC): Social Development, The World Bank; 2004. Available: http://documents.worldbank.org/curated/en/
327691468779445304/pdf/310420PAPER0So1ity0SDP0Civic0no1076.pdf (accessed 2020 Apr. 1).

74. McGowan J, Sampson M, Salzwedel DM, et al. PRESS peer review of electronic search strategies: 2015 guideline statement. 7 Clin Epidemiol 2016; 75:40-6.

Affiliations: Bruyère Research Institute (Kaur), University of Ottawa, Ottawa, Ont.; Family Medicine Residency Program (Kaur), Department of Family Medicine, McMaster University, Hamilton, Ont.; C.T. Lamont Primary Health Care Research Centre (Saad, Magwood), Bruyère Research Institute, Ottawa, Ont.; Department of Medicine (Alkhateeb), Schulich School of Medicine, Toronto, Ont.; Interdisciplinary School of Health Sciences (Magwood), University of Ottawa; Bruyère Research Institute (Mathew), Ottawa, Ont.; Centre de médecine familiale de Wakefield (Khalaf), Wakefied, Que.; Centre integré de santé et de services sociaux de l'Outaouais de Hull (Khalaf), Gatineau, Que.; Departments of Family Medicine and Epidemiology, and Community Medicine (Pottie), University of Ottawa; Institut du Savoir Montfort, Ottawa, Ont.

Contributors: Harneel Kaur and Kevin Pottie conceived and designed the work. All authors contributed to the acquisition, analysis and interpretation of data. Harneel Kaur, Ammar Saad, Olivia Magwood, Christine Mathew and Kevin Pottie drafted the manuscript. All of the authors revised it critically for important intellectual content, gave final approval of the version to be published and agreed to be accountable for all aspects of the work.

Content licence: This is an Open Access article distributed in accordance with the terms of the Creative Commons Attribution (CC BY-NC-ND 4.0) licence, which permits use, distribution and reproduction in any medium, provided that the original publication is properly cited, the use is noncommercial (i.e., research or educational use), and no modifications or adaptations are made. See: https://creativecommons.org/licenses/ by-nc-nd/4.0/

Data sharing: The authors used publicly available data for the analysis in this study.

Supplemental information: For reviewer comments and the original submission of this manuscript, please see www.cmajopen.ca/content/9/2/ E681/suppl/DC1. 